\title{
MORTALITY DUE TO CERVICAL CANCER, 1996-2011, SANTA CATARINA, BRAZIL
}

\author{
Kathleen Mary Hegadoren ${ }^{1}$, Vera Radunz², Maria de Lourdes de Souza3, Fernanda Pacheco de Faria ${ }^{4}$, Jean \\ Carlos Bonissoni da Silva ${ }^{5}$ Lúcio José Botelho
}

${ }^{1}$ Ph.D. Professor at University of Alberta, College of Nursing, Canada. E-mail: kmh3@ualberta.ca

${ }^{2}$ Ph.D. in Nursing. Professor, Universidade Federal de Santa Catarina (UFSC), Graduate Nursing Department. Florianópolis, Santa Catarina, Brazil. E-mail: radunz@ccs.ufsc.br

${ }^{3}$ Ph.D. in Public Health. Collaborator of the Graduate Nursing Program at UFSC. Florianópolis, Santa Catarina, Brazil. E-mail: lourdesr@repensul.ufsc.br

${ }^{4}$ Bachelor of Medicine from UFSC. Florianópolis, Santa Catarina, Brazil. E-mail: fernandapacheco.faria@gmail.com

${ }^{5}$ Undergraduate medical student, Undergraduate Medical Program. Florianópolis, Santa Catarina, Brazil. E-mail: jcbsilva12@ gmail.com

${ }^{6}$ M.Sc. in Public Health. Professor, Public Health Department, at UFSC. Florianópolis, Santa Catarina, Brazil. E-mail: lucio. botelho@ufsc.br

\begin{abstract}
Population-based quantitative study. This study's objectives were to examine the influence of regions, age, and time on cervical cancer mortality. We analyzed cervical cancer mortality rates in the State of Santa Catarina, Brazil between 1996 and 2011. Data were obtained from the Mortality Information System from the Brazilian Ministry of Health in 2013. Data were analyzed based on descriptive epidemiology. Cervical cancer mortality rates ranged from 3.6 to 5.0/100,000 women. Rates were higher among older women, with the highest rates after the age of 70. Women's awareness regarding the importance of the Pap smear test in their health checkups may differ across ages and regions of residence. The frequency of Pap smears should change due to the trend of mortality rates observed over time.
\end{abstract}

DESCRIPTORS: Neoplasms. Uterine cervical neoplasms. Cause of death

\section{MORTALIDADE POR CÂNCER DE COLO UTERINO, 1996-2011, SANTA CATARINA, BRASIL}

RESUMO: Estudo quantitativo de base populacional. Os autores definiram como objetivo para o estudo examinar as influências da região, idade e tempo sobre a mortalidade por câncer de colo de útero. Foram analisadas as taxas de mortalidade que ocorreram no Estado de Santa Catarina, entre 1996 e 2011. Os dados foram obtidos do Sistema de Informações sobre Mortalidade do Ministério da Saúde, Brasil, durante o ano de 2013. A análise dos dados foi realizada com base na epidemiologia descritiva. As taxas de mortalidade por câncer de colo de útero variaram de 3,6 a 5,0/100.000 mulheres. Essas taxas aumentaram nos grupos etários mais avançados, apresentando os valores mais elevados após os 70 anos. A consciência da mulher sobre a importância do Papanicolaou em suas avaliações de saúde pode ser diferente conforme a idade e as regiões nas quais vivem. A frequência do Papanicolaou deve mudar, observando-se a tendência das taxas de mortalidade ao longo do tempo.

DESCRITORES: Neoplasias. Neoplasias do colo do útero. Causa de morte.

\section{MORTALIDAD POR CÁNCER DE CUELLO DEL ÚTERO, 1996-2011, SANTA CATARINA, BRASIL}

RESUMEN: Estudio cuantitativo de base poplacional. Los autores tienen como objectivo examinar las influencias de la región, la edad y el tiempo en la mortalidad por cáncer de cuello uterino. Las tasas de mortalidad que ocurrieron en el Estado de Santa Catarina, entre 1996 y 2011 fueron analizados. Los datos fueron obtenidos del Sistema de Información de Mortalidad del Ministerio de Salud, Brasil, en el año 2013. El analisis de los datos fue realizada fundamentada en la epidemiologia descritiva. Las tasas de mortalidad por cáncer de cuello uterino variaron desde 3,6 hasta 5,0/100.000 mujeres. Estas tasas aumentaron en los grupos de mayor edad y presentaron los valores más altos después de 70 años. La conciencia de la mujer acerca de la importancia del la prueba de Papanicolaou en sus evaluaciones de salud, puede ser diferente según la edad y las regiones en las que viven. La frecuencia de la prueba de Papanicolaou debe cambiar mediante la observación de la evolución de las tasas de mortalidad en el tiempo.

DESCRIPTORES: Neoplasias. Neoplasias del cuello uterino. Causa de muerte. 


\section{INTRODUCTION}

Cancer, in its different forms, caused 7.6 million deaths around the world in 2008 and represented $13 \%$ of all deaths in that year. Increased life expectancy, smoking and drinking, sedentariness, and poor eating habits are associated with the increased incidence of cancer. ${ }^{1}$ Of the different types of cancer affecting women, cervical cancer (CCU) is the second most incident cancer $(15.2 / 100,000$ women) and has the third highest rate of mortality (7.8/100,000 women). There are, however, differences in the incidence of cervical cancer across countries. ${ }^{2}$ In 2008 for instance, the incidence of cervical cancer (expressed as a number of new cases per 100,000 women) ranged from 7.8, in the United States, to 11 in the United Kingdom, and 17.8 around the world..$^{3-5}$

Cervical cancer is the main cause of death due to cancer in Colombia, with regional mortality rates ranging from 20.0 to $27.0 / 100,000$ women. ${ }^{6}$ Brazil follows the world trend in which cervical cancer is the third main cause of death due to cancer among women. ${ }^{7}$ Differences among countries suggest that guidelines concerning early detection strategies, such as the Pap smear exam, need to take into account regional contexts.

Pathological changes observed in cervical cancer can be divided into four stages according to the level of tissue invasiveness, from I to IV. Early detection and treatment is beneficial but early detection and treatment decreases the risk of being at Stage 4 at the time of detection, and thus the increase in survival is so much more. ${ }^{8}$ This difference in survival rates led the Brazilian government to establish guidelines to guide state and city governments to implement early detection strategies within regions. There were, however, no standard guidelines in regard to the age women should have routine exams, how frequently screenings should occur when implemented, or when it is safe to stop screening older women. The conventional Pap smear shows a sensitivity of $76 \%$ in detecting cervical cancer. ${ }^{9}$ Global sensitivity, however, depends on repetitive exams performed at regular intervals. When considering the relatively slow progression of this type of cancer and the high survival rates with early detection, analysis of mortality rates can reflect the efficiency of early detection strategies. Specific detection methods, consistently applied, should significantly reduce the incidence of cervical cancer in stages III and IV. Access to specialized treatment, which we do not discuss in this paper, would also greatly contribute to the variation observed in mortality rates.

Given the slow progression of cervical cancer and the significant decrease in mortality when there is early detection, it is imperative that mortality data be analyzed to verify whether early detection guidelines from other countries are appropriate for the local context. Healthcare workers need to verify whether or not their practices contribute to increased detection of women at a greater risk of developing cervical cancer. Hence, mortality data concerning cervical cancer in the state of Santa Catarina, SC, Brazil from 1996 to 2011 were analyzed in regard to regional patterns, age and changes over time.

\section{METHOD}

This is a population-based study conducted with secondary data collected in 2013 from the Mortality Information System (SIM), SUS Information Department (DATASUS), Ministry of Health, Brazil. ${ }^{10}$

The study's population comprised individuals who died from cervical cancer in Santa Catarina and whose deaths were recorded in the SIM. The Specific Mortality Rate (SMR) from 1996 to 2001 is represented by:

$S M R=\frac{\text { number of deaths due to } C C U \text { per year }}{\text { population of women per year }} \times 100.000$

The code from the $10^{\text {th }}$ IDC for the cause of death was: C53 - Malignant neoplasm of cervix uteri. $^{11}$

Data analysis, based on descriptive epidemiology, took into account SMRs due to neoplasm of cervix uteri in the state of Santa Catarina, Brazil dividing by age groups: up to 29 years old, from 30 to 39 years old, from 40 to 49,50 to 59 , 60 to 69,70 to 79 , and 80 years old or older, to establish comparisons between intervals of age per year and to study the historical series in the same age group. SMRs were verified in the period from 2000 to 2011 in each of the macro regions defined by the government of the state of Santa 
Catarina through comparison between them in specific years and in historical series. Macroregions include: Greast Oeste, Midwest, Itajaí Valley, Itajaí River Mouth, North Plateau, Northeast, Great Florianópolis, South and Mountain Range Catarinense.

Data are presented in tables and graphs to facilitate visualization of how cervical cancer manifested over time in the historical series under study.

\section{RESULTS}

The state of Santa Catarina, located in the South region of Brazil, has a territorial extension of $281.748,538 \mathrm{~km}^{2}$ with a population of $6,248,436$ inhabitants in 2010 . Of these, $50.4 \%$ were women, i.e. 3,148,076 women in different age groups.

From 1996 to 2011, SMRs for cervical cancer ranged from 3.6 to 5.5 per 100,000 women. There were, however, variations among age groups and over time, ranging from 2.8 to 35.0 per 100,000 women (Table 1).

Table 1 - Specific mortality rates due to cervical cancer per year and age group in Santa Catarina, Brazil, from 1996 to 2011

\begin{tabular}{lcccccccc}
\hline Year & $\begin{array}{c}\text { Up to 29 } \\
\text { years old }\end{array}$ & $\begin{array}{c}\mathbf{3 0} \text { to } \mathbf{3 9} \\
\text { years old }\end{array}$ & $\begin{array}{c}\mathbf{4 0} \text { to } \mathbf{4 9} \\
\text { years old }\end{array}$ & $\begin{array}{c}\mathbf{5 0} \text { to } \mathbf{5 9} \\
\text { years old }\end{array}$ & $\begin{array}{c}\mathbf{6 0} \text { to } \mathbf{6 9} \\
\text { years old }\end{array}$ & $\begin{array}{c}\mathbf{7 0} \text { to } \mathbf{9 9} \\
\text { years old }\end{array}$ & $\begin{array}{c}\mathbf{8 0} \text { years } \\
\text { old or } \\
\text { older }\end{array}$ & $\begin{array}{c}\text { SMR } \\
\text { year }\end{array}$ \\
\hline 1996 & 0.1 & 4.5 & 9.8 & 14.3 & 15.0 & 15.2 & 4.6 & 4.0 \\
1997 & 0.8 & 4.4 & 9.3 & 13.5 & 22.5 & 13.3 & 27.0 & 4.8 \\
1998 & 0.3 & 3.1 & 11.6 & 22.0 & 13.7 & 16.4 & 22.2 & 4.8 \\
1999 & 0.5 & 5.0 & 16.0 & 19.4 & 13.5 & 16.2 & 26.3 & 5.5 \\
2000 & 0.1 & 4.3 & 13.1 & 10.6 & 14.3 & 22.8 & 35.0 & 4.9 \\
2001 & - & 3.7 & 11.2 & 14.4 & 17.4 & 9.1 & 27.5 & 4.6 \\
2002 & 0.1 & 5.4 & 8.9 & 10.8 & 11.3 & 13.8 & 3.3 & 4.0 \\
2003 & 0.2 & 2.7 & 9.2 & 11.8 & 14.5 & 12.2 & 19.2 & 4.0 \\
2004 & 0.2 & 3.8 & 8.4 & 10.8 & 10.6 & 11.5 & 17.9 & 3.9 \\
2005 & 0.3 & 3.2 & 6.1 & 13.3 & 17.4 & 21.1 & 17.2 & 4.4 \\
2006 & 0.3 & 4.1 & 7.7 & 7.1 & 7.3 & 11.4 & 21.5 & 3.6 \\
2007 & 0.1 & 4.1 & 8.5 & 12.1 & 16.1 & 18.0 & 15.8 & 4.8 \\
2008 & 0.3 & 4.1 & 7.3 & 8.1 & 14.9 & 18.4 & 8.5 & 4.3 \\
2009 & 0.1 & 2.8 & 9.4 & 10.6 & 10.5 & 14.9 & 32.3 & 4.6 \\
2010 & 0.4 & 3.9 & 8.1 & 9.1 & 9.0 & 12.7 & 7.84 & 4.1 \\
2011 & 0.3 & 4.5 & 8.9 & 10.6 & 13.5 & 16.3 & 19.6 & 5.0 \\
\hline
\end{tabular}

Source: Ministry of Health /Secretary of Health Surveillance - Mortality Information System (SIM), 2012. ${ }^{10}$

Mortality by age groups shows a trend of increased SMR in older age groups, with more individuals in the age range of 70 years old and older. The highest rates were for 80 years old or older women $(35 / 100,000)$ in 2000 (Table 1).

Specific data by macro-region in Santa Cata- rina are only available beginning in 2000. In this period, as shown in figure 1 and table 2, there is variability among the regions. The highest rate of SMR by CCU was 10.4/100,000 women in Montain Range Catarinense, followed by Itajaí Valley and the Northeast Region, greater than 5.21 (Table 2). 


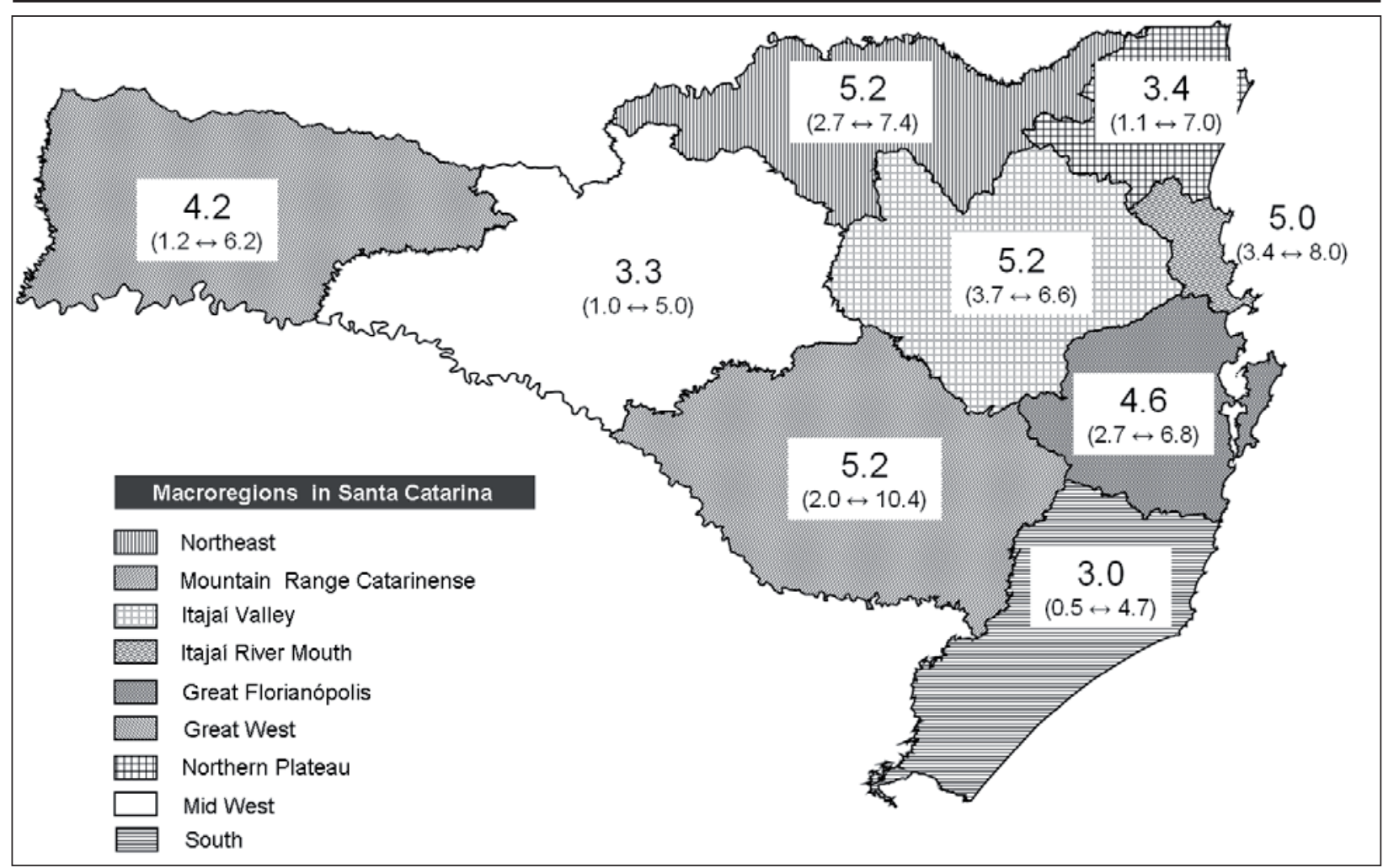

Figure 1 - Specific Mortality rate by cervical cancer, per 100,000 women, macroregions in the state of Santa Catarina, Brazil, from 2000 to 2011

Table 2 - Specific Mortality rate by cervical cancer by macroregions in the state of Santa Catarina, Brazil, from 2000 to 2011

\begin{tabular}{|c|c|c|c|c|c|c|c|c|c|c|c|c|c|}
\hline Region & ఫ్రి & ธ్రి & ఫิ ڤ్ & ర్లి & ఫ્ડે & ஜ્రి & ఫ్రి & ક્సે & ఫ્సે & ठ્సે & 오․ & تें & $\sum_{\omega}^{\infty} \cdot \bar{d}$ \\
\hline Northeast & 5.2 & 3.1 & 2.7 & 6.2 & 4.5 & 5.3 & 5.2 & 6.7 & 5.4 & 7.4 & 4.8 & 5.5 & 5.2 \\
\hline Mountain Range Catarinense & 5.5 & 5.5 & 3.4 & 4.1 & 3.4 & 7.3 & 7.9 & 2 & 4.6 & 3.3 & 5.5 & 10.4 & 5.2 \\
\hline Itajaí Valley & 4.6 & 3.7 & 5.1 & 4.4 & 5 & 4.3 & 5.8 & 5.9 & 5.1 & 6 & 6.6 & 5.4 & 5.2 \\
\hline Itajaí River Mouth & 8 & 5.8 & 6.1 & 3.6 & 4.4 & 7.9 & 5.7 & 4.7 & 3.9 & 3.4 & 3.5 & 3.9 & 5 \\
\hline Great Florianópolis & 6.7 & 6.8 & 2.7 & 5.1 & 4 & 5.5 & 3.3 & 4.2 & 5.1 & 2.9 & 3.8 & 5.3 & 4.6 \\
\hline Great West & 3.9 & 5.3 & 6.2 & 5.6 & 4.4 & 3.2 & 1.2 & 3.8 & 4.7 & 5.5 & 3.3 & 3.3 & 4.2 \\
\hline Northern Plateau & 3 & 1.2 & 2.4 & 2.3 & 7 & 1.1 & 0 & 5 & 5 & 3.3 & 3.9 & 6.8 & 3.4 \\
\hline Midwest & 5 & 4.2 & 3.1 & 3.5 & 2.1 & 3 & 3 & 3.6 & 1 & 4.4 & 2.7 & 4 & 3.3 \\
\hline South & 3 & 4.7 & 3.8 & 0.5 & 2.1 & 3 & 1.6 & 4.2 & 2.5 & 3.8 & 3.1 & 4.1 & 3 \\
\hline Santa Catarina & 4.9 & 4.6 & 3.9 & 4 & 3.9 & 4.4 & 3.6 & 4.6 & 4.2 & 4.6 & 4.1 & 5 & 4.3 \\
\hline
\end{tabular}

Source: Ministry of Health / Secretary of Health Surveillance - Mortality Information System (SIM), 2012.10

Mortality rates due to cervical cancer in the state of Santa Catarina changed very little in the period from 2000 to 2011 (ranging from 3.6/100.000 women in 2006 to 5.0/100,000 women in 2011). Regional rates, however, revealed signifi- cant variation over time. There was no consistent pattern of change among regions and times, with the highest and lowest rates varying greatly. Three regions showed higher rates in recent years. For instance, the Northeast of Santa Catarina presented 
a rate of $7.4 / 100,000$ women in 2009 , but only $2.7 / 100,000$ women in 2002. The rate observed in Montain Range Catarinense is the highest in 2011 with 10.4/100,000 women and the lowest in 2007 with 2.0/100,000 women. Mortality rates in Itajaí Valley were at their highest in 2010 (6.6/100,000 women) and the lowest rate was observed in 2001 (3.6/100,000 women). The other five regions presented lower rates over time. Variations in rates may be due to inaccuracy in data recording; note this study was based on secondary data. For instance, mortality rates in Northern Plateau ranged from $0.0 / 100.000$ women in 2006 to $7.0 / 100,000$ women in 2004.

\section{DISCUSSION}

Analysis of the entire period showed a non-significant increase in SMR for cervical cancer in the state of Santa Catarina, Brazil (from 4.9/100,000 women in 2000 to 5.0/100,000 women in 2011), though the rates varied in the period, ranging from the lowest global rate 3.6/100,000 women in 2006 to the highest 5.0/100,000 in 2011. Complex interactions among multiple systems and individual factors over time probably contributed to the rates observed in Santa Catarina and for the variability observed among regions. Many changes in Brazilian heath policy and other specific initiatives in the health field directed to Brazilian women helped to define and implement strategies intended to detect breast cancer and cervical cancer early.

In 1983, the Program for Integrated Women's Health Care was created and it was a step forward in terms of the healthcare provided to women. The program, however, had little impact on the implementation of polices concerning the Unified Health System (SUS) in 1990, which triggered a reorganization and regionalization of PHC. Only in 1995 did the government again include the women's health topic in the agenda, probably influenced by the conference in Cairo sponsored by UN in 1994. ${ }^{12}$ These changes in polices have contributed to improved data recording concerning women's health. It was expected, however, that improved data recording would also improve prevention and early treatment of cervical cancer, resulting in lower SMRs. But data presented here do not meet this expectation.

Hence, mortality rates would be higher given improved records. Variability among the years in various regions does not match this perspective. In the United States, the incidence and mortality rates by cervical cancer fell $50 \%$ over the last three decades. ${ }^{13}$ Even though this incidence is also observed in other developed countries, developing countries do not follow. In terms of mortality, CCU was the cause of 275,000 deaths in 2008 and approximately $88 \%$ of them took place in developing countries. ${ }^{2}$ According to a study conducted by the Pan-American Health Organization, the number of SMRs due to cervical cancer in Latin America and the Caribbean was constant from the 1960s to 1996 with mortality ranging from 5.0 to 6.0 deaths per 100,000 women. These data are not in agreement with those reported by other studies, such as the reports of 1.4 and 1.7 per 100,000 women in the United States and Canada, respectively in the 1990s. Mortality by cervical cancer is high in Mexico, Chile and Costa Rica, especially among women younger than 40 years old, as a result of a greater emphasis on the follow-up of young women accessing healthcare services for prenatal care or family planning. ${ }^{14}$

The increased SMR by age observed in the state of Santa Catarina reflects the Brazilian context with the highest mortality of 35.0/100,000 among 80 years old or older women. The second highest rate $(22.8 / 100,000)$ is among women from 70 to 79 years old. These figures may be related to the fact that public policies in the women's health field are predominantly focused on women of reproductive age. ${ }^{12}$ Older women may live many years with cervical cancer in its initial stage without a conclusive diagnosis and proper intervention. American guidelines for cervical cancer screening available at the site for the U.S. Preventive Services Task Force ${ }^{15}$ do not recommend screening for 65 years old or older women, but note that such a policy is only appropriate for women who were previously properly screened and are not at high risk for CCU. Hence, it is prudent that the state of Santa Catarina keep screening 65 years old or older women until a systematic documentation system recording cytology results is implemented and healthcare workers are able to properly control previous screenings. In 2005, the Brazilian Program for the Control of Cervical Cancer established that controlling cervical and breast cancer was a key component to be incorporated into state and city plans. ${ }^{16}$ Time over the course of life has to be taken into account, especially among older women, who may or may not seek preventive healthcare programs, until these 
political decisions are implemented in healthcare services with effective actions concerning routine exams.

Inequalities observed in the state of Santa Catarina may reflect varied degrees of the implementation of public policies in the different regions and, therefore, a lack of commitment on the part of public authorities in regard to the SUS principals concerning universal and equal access to healthcare services and treatment. It is also possible that screening is implemented differently among the different cities, with a lack of universal access to diagnostic tests, especially among women 50 years old or older. Additionally, a lack of control over the quality of laboratory tests, resulting in false negatives and false positives, disqualifies the services and generates a lack of trust in the services. The social and educational conditions of women may impede them from returning to the healthcare services to discuss the results of the cytology exams and, consequently, from being categorized according to groups of risk for regular follow-up. This situation may worsen if the healthcare service does not adopt the practice of actively searching for women whose exam results demand a more careful assessment or who are considered to be at a high risk of developing cervical cancer.

Even after CCU is detected and treated, women may experience recurrence at the same site, generally within two years after the first treatment. The prognosis in regard to the recurrence time depends on the stage of the first diagnosis, type of treatment, use of adjuvant hormone therapy, and whether the patient was asymptomatic or symptomatic at the time the recurrence was detected. ${ }^{17}$ One study assessing patients with CCU between 2004 and 2008 in a public service in Criciúma, Santa Catarina, Brazil corroborates this information. It reports that recurrences affected $36.4 \%$ of the women, while $75 \%$ of these were locoregional and in the remaining patients were metastases. All the recurrences occurred within three years of the initial disease. Half of the initial diagnoses, however, included stage IIIB and that may explain the high incidence of recurrences. ${ }^{18}$ Even though early detection of a recurrence does not change the prognosis, advancements in the early detection of the initial lesion can enable improved treatment and results. ${ }^{17}$

Assessment of SMR by CCU provides indirect data in regard to the level of access of the fe- male population to screening services because both are related. One study of Swedish women reports that the rate of five-year survival among those diagnosed by screening was $95 \%$, while women who experienced symptomatic CCU had a fiveyear survival rate of $69 \%$. The rates of cure among these women were $92 \%$ and $66 \%$, respectively. Among the group of women with CCU diagnosed when the disease was symptomatic, the rate of cure for those within the recommended screening interval was $74 \%$, while for those with late screening rate of cure was $60 \%$ lower. ${ }^{19}$ These findings support the need for regular screening as a way to reduce mortality among women with CCU, because the outcome is better when the lesion is identified before symptoms appear. According to the Pan-American Health Organization (PAHO) and World Health Organization (WHO), in order to achieve quality standards for the screening of women in regard to cervical cancer, $80 \%$ to $85 \%$ of the female population should be consistently screened. ${ }^{20}$

In the Brazilian context, however, late diagnosis is still the most common situation. It may be attributed to an interaction among factors such as the female population's difficult access to services, limited and inconsistent services or healthcare programs, and lack of experience of the human resources involved in the detection of cancer and health care delivery. Additionally, the inability of governments to meet the demand within PHC units and the challenges faced by city and state managers to define and implement a well-coordinated documentation system for the spectrum of cancer treatment from early detection strategies, treatment, and follow-up in the long term should also be taken into account.

There are health policies in Brazil that establish screening of cervical cancer, as well as treatment services that are sufficient to produce health statistics free of high rates of cancer in the next 10 years, as long as CCU is detected early. Data collected from the state of Santa Catarina, however, suggest that policies have not yet significantly impacted mortality rates. Campaigns to sensitize the public have been useful in other countries and also for other health problems. Expanding the awareness of women may increase demand for routine exams but Brazilian healthcare workers should also take the responsibility to promote awareness and be prepared to meet women's care 
needs. Brazilian nurses are capable of performing Pap smears, but there are no current data to verify whether this screening strategy is a consistent component of nursing practice. Nurses working in PHC could play a leadership role and actively promote Pap smears among women at all stages of life. Nurses could also help identify women who could benefit from a more detailed assessment through tests and/or colposcopy. Nurses need to increase their understanding regarding women's health issues beyond traditional issues such as reproduction, pregnancy, delivery and maternity, to include the entire cycle of life within the context of the family, community and nation.

Various limitations are observed in the data analysis. The total population of women (denominator in the SMR formula) includes women who had received a hysterectomy. Therefore, the real mortality rate may be even higher than what is reported here, though in another study conducted with histerectomized women, no global difference was found. ${ }^{21}$ Other elements contributing to mortality rates due to CCU and potential regional differences, not discussed here, may include: treatment adequacy, access to treatment, the professionals' experience in performing Pap smears, and environmental risks (e.g. exposure to diethylstilbestrol).

Another important factor is the discovery of a relationship between CCU and the human papilloma virus (HPV), a sexually transmitted disease. Two of the most common genotypes of HPV contribute to $70 \%$ of CCU. ${ }^{22-24}$ Risk factors for cervical cancer related to HPV include early sexual initiation, type of contraceptive methods, the prolonged use of oral contraceptives, greater number of children, multiple partners, low socioeconomic level, and smoking. ${ }^{6,25}$ Vaccines against HPV are 99\% efficient in preventing pre-cancerous lesions associated with HPV in young women. Vaccination campaigns against HPV in other countries produced a significant decrease in the prevalence of $\mathrm{HPV}$, which translates into decreased future rates of CCU. ${ }^{26-27}$ In Brazil, only after January 2014 was a vaccination against HPV implemented free of cost for young women, though there is growing evidence that young men should also be vaccinated. ${ }^{23}$ The potential benefits of this program with its respective decrease in mortality rates in the state of Santa Catarina will take a few years to become evident.

\section{CONCLUSIONS}

The CCU mortality rates identified in the state of Santa Catarina showed little global improvement in the studied period. Older women presented the highest rates of mortality, raising important questions concerning screening, which require greater attention: How can public health policies concerning cervical cancer screening can be improved to reach women in different age groups? What practices can be temporarily used until international guidelines can be definitively implemented? How can routine exams be tracked so that the screening history of these women can be easily available for healthcare workers? What are the current professional practices concerning screening? Nurses play an important role in leading health promotion, and have their own set of questions: How can nursing training programs qualify nurses to expand their role in the early detection of cervical cancer in the routine follow-up of women at high risk and women after treatment? Does the variability of SMR in age groups reflect environmental systems or factors over time, or a combination of factors that need to be studied in each region to create significant local responses? These and other questions should be included in the research agenda concerning cervical cancer in the state of Santa Catarina, Brazil.

\section{REFERENCES}

1. World Health Organization (WHO). Media centre: cancer. Genebra: WHO; (C 2014. [página na Internet]. [atualizado 2014 Fev; acesso 2014 Maio 19]. Disponível em: http:/ / www.who.int/mediacentre/ factsheets/fs297/en/index.html

2. Ferlay J, Shin HR, Bray F, Forman D, Mathers C, Parkin DM. GLOBOCAN 2008 (IARC) [página na Internet]. Section of cancer information; c2011 [atualizada 2008; acesso Out16]. Disponível em: http://www.iarc.fr/en/research-groups/sec1/

3. Cancer Research UK. Cervical cancer incidence statistics [página na Internet]; c2009 [atualizada 2012 Jun 01; acesso 2012 Out 18]. Disponível em: http:/ / www.cancerresearchuk.org/cancer-info/ cancetstats/types/cervix/incidence/uk-cervicalcancer-incidence-statistics

4. Centers for Disease Control and Prevention (CDC). Cervical cancer statistics [página na internet]; c19992008 [atualizada 2012 Abr 30; acesso 2012 Out 18]. Disponível em: http://www.cdc.gov/cancer/ cervical/statistics 
5. Arzuaga-Salazar MA, Souza ML, Lima VLA. O câncer de colo do útero: um problema social mundial. Rev Cubana Enferm [online]. 2012 Jan-Mar [acesso 2012 Otc 18]; 28(1):63-73. Disponível em: http:// scielo.sld.cu/pdf/enf/v28n1/enf07112.pdf

6. Munoz N, Bravo LE. Epidemiology of cervical cancer in Colombia. Colomb Med (Cali). 2012 Dec 30;43(4):298-304.

7. Silva GA, Girianelli VR, Gamarra CJ, BustamanteTeixeira MT. Evolução da mortalidade por câncer de colo de útero no Brasil, 1981-2006. Cad Saúde Pública [online]. 2010 Dez [acesso 2012 Out 18]; 26(12):2399407. Disponível em: http:/ /www.scielosp.org/pdf/ csp/v26n12/18.pdf

8. About.com Cancer [página na Internet]. Cervical cancer survival rates; c2003-06 [atualizada 2006 Dec 01; acesso 2012 Oct 18]. Disponível em: http:/ / www. cancer.about.com/od/cervicalcancerbasics/a/ survivalrates.htm

9. Cuzick J, Szarewski A, Cubie H, Hulman G, Kitchener H, Luesley D, et al. Management of women who test positive for high-risk types of human papillomavirus: the HART study. Lancet. 2003 Dec 6; 362(9399):1871-6.

10. Ministério da Saúde (BR). Sistema de Informações sobre Mortalidade (SIM); 2007 [acesso 2007 Set 20]. Disponível em: http:/ / www.datasus.gov.br/

11. Organização Mundial da Saúde (OMS). CID-10 Classificação estatística internacional de doenças e problemas relacionados à saúde: $10^{\mathrm{a}}$ revisão. $6^{\mathrm{a}}$ ed. São Paulo (SP): Centro Colaborador da OMS para a Classificação de Doenças em Português/EDUSP; 2001.

12. Souto KMB. A política de atenção integral à saúde da mulher: uma análise de integralidade e gênero. SER Social [online]. 2008 Jan-Jun [acesso 2012 Out 18]; 10(22):161-82. Disponível em: http://seer.bce. unb.br/index.php/SER_Social/article/view/17/18

13. Nacional Cancer Institute [página na Internet]. Cancer topics: cervical cancer; [atualizada 2011 Oct; acesso 2012 Oct 20]; Disponível em: http:/ /www. cancer.gov/cancertopics/types/cervical

14. Robles SC, White F, Peruga A. Trends in cervical cancer mortality in the Americas. Bull Pan Am Health Organ. 1996 Dec; 30(4):290-301.

15. U.S. Preventive Services Task Force [página na Internet]. Screening for cervical Cancer; [atualizada 2012 March; acesso 2013 Fev 27]. Disponível em: http://www.uspreventiveservicestaskforce.org/ uspstf/uspscerv.htm

16. Instituto Nacional de Câncer (INCA) [página na Internet]. Programa Nacional de Controle do Câncer de Colo de Útero; 2005 [atualizada 2011 Abr; acesso
2013 Fev 27]. Disponível em: http://www1.inca. gov.br/inca/Arquivos/PROGRAMA_UTERO_ internet.pdf

17. Baalbergen A, Helmerhorst TJM, Burguer WC. Prognostic factors that predict survival after relapse of cervical cancer. CME J Gynecol Oncol [online]. 2001 [acesso 2013 Fev 27]; 6:391-7. Disponível em: http://www.researchgate.net/journal/1219-9087_ CME_Journal_of_Gynecologic_Oncology

18. Bonardi LH, Silva FR, Souza MV, Sombrio SN, Silva BR, Rosa MI. Análise epidemiológica de pacientes com câncer de colo de útero num serviço público de oncologia de Criciúma-SC. Arq Catarin Med [online]. 2010 [acesso $2013 \mathrm{Fev}$ 27]; 39(3):34-8. Disponível em: http://www.acm.org.br/revista/ pdf/artigos/813.pdf

19. Andrae B, Andersson TM, Lambert PC, Kemetli L, Silfverdal L, Strander B, et al. Screening and cervical cancer cure: population based cohort study. BMJ. 2012 Mar 01; 344:e900. doi: 10.1136/bmj.e900

20. Arzuaga-Salazar MA, Souza ML, Martins HEL, Locks MTR, Monticelli M, Peixoto HG. Câncer de colo do útero: mortalidade em Santa Catarina, Brasil, 2000 a 2009. Texto Contexto Enferm [online]. 2011 Jul-Set [acesso 2013 Fev 27]; 20(3):541-6. Disponível em: http://www.scielo.br/pdf/tce/v20n3/16.pdf

21. International Agency for Research on Cancer (IARC). France [atualizada 2014; acesso 2014 maio 15]. Disponível em: http://www.iarc.fr/

22. Pirog EC, Lloveras B, Molijn A, Tous S, Guimerà $\mathrm{N}$, Alejo $\mathrm{M}$, et al. HPV prevalence and genotypes in different histological subtypes of cervical adenocarcinoma, a worldwide analysis of 760 cases. Mod Pathol. 2014 Apr 25. doi: 10.1038/ modpathol.2014.55

23. Stanley MA, Sterling JC. Host responses to infection with human papillomavirus. In: Ramírez-Fort MK, Khan F, Rady PL, Tyring SK, editors. Human papillomavirus: bench to bedside. Curr Probl Dermatol. Basel: Karger; 2014; 45:58-74.

24. Malik H, Khan FH, Ahsan H. Human papillomavirus: current status and issues of vaccination. Arch Virol. 2014 Feb;159(2):199-205.

25. Kitchener HC, Denton K, Soldan K, Crosbie EJ. Developing role of HPV in cervical cancer prevention [Review]. BMJ [online]. 2013 Aug 7 [acesso 2014 Maio. 25]; 347:f4781. Disponível em: http://www.bmj.com/content/bmj/347/bmj. f4781.full.pdf

26. Tabrizi SN, Brotherton JM, Kaldor JM, Skinner SR, Cummins E, Liu B, et al. Fall in human papillomavirus prevalence following a national vaccination program. J Infect Dis. 2012 Dec 1; 206(11):1645-51. doi: 10.1093/infdis/jis590 
27. Marowitz LE, Hariri S, Lin C, Dunne EF, Steinau M, McQuillan G, et al. Reduction in human papillomavirus (HPV) prevalence among young women following HPV vaccine introduction in the United
States, National Health and Nutrition Examination Surveys. J Infect Dis. 2013 Aug 1 [acesso 2014 Maio. 25]; 208(3):385-93. Disponível em: http:/ /jid.oxfordjournals.org/content/208/3/385.full.pdf+html 